\section{BARAN, Kazimierz}

Prof. Dr. habil

University of Applied Sciences in Tarnow
DOI: $10.15170 /$ DIKE.2020.04.01.03

\title{
The Concept of Treason in the English Legal System between the Middle Ages and the Reign of the Tudors
}

In the Middle Ages the concept of treason in England relied on the 1352 Treason Statute and the interpretation of its clauses. Since statutory list of specimens of treason was considered non-exhaustive, the 1352 law included a proviso that allowed to submit to the king in parliament cases that aroused doubt on whether they were treason or not. This led to the development of Act of Attainder, i. e. semi-judicial procedure which allowed to declare in individual cases some acts to be treasons while applying a typical law-creating modus procedendi (i. e. formulating a bill of Attainder against the alleged perpetrator, the bill had to pass through both houses of parliament and be accepted by the monarch through his assent). The Act of Attainder dynamically developed under the Tudors, particularly during the reign of Henry VIII who used to set it on foot whenever he desired to liquidate his real or alleged opponents. In doing this he could count on parliaments that where docile to him. The henrician Acts of Attainder were characterized by scarcity of evidence furnished to support the accusations, the accused being practically deprived of the possibility to defend themselves. Apart from developing Acts of Attainder, the Tudors took also to modifying the traditional concept of treason and inspired the adoption by parliaments new treason statutes that went beyond the standard at one time set by the 1352 law. The new treason statutes punished utterances considered to be ill-disposed toward the monarch but non-related to any conspiracy. The last decades of the rule of the Tudor dynasty witnessed a slow decline of exploiting the Act of Attainder, however the tendency to resort to the new treason statutes survived.

Keywords: treason, Act of Attainder, modus procedendi, Tudor dynasty, English legal system

\section{Treason before the Tudors'reign}

In the Middle Ages the English concept of treason became consolidated by the Statute passed in 1352 under the reign of Edward III. Basically speaking the law of 1352 granted the statutory form to what already functioned in common law as treason. Prior to 1352 Statute, treason amounted to the cases of breach of allegiance that every subject was due to the king. ${ }^{1}$ What however at that time may have necessitated the clear statutory articulation of specimens of treason was an arbitrary power exercised by the judges in deciding what the breach of allegiance consisted in. The complaints critical of that situation, lodged with the Royal Court by highly-positioned subjects, doubtless contributed to the formulation of the bill of treason which turned into law after it had

\footnotetext{
${ }^{1}$ TASWELL-LANGMEAD, English Constitutional History 572.
} 
been passed in the houses and granted assent by the monarch. ${ }^{2}$ The adoption of the Treason Statute aimed to eliminate doubtful interpretation of treason due to which this crime could be attributed to those blamed for "accroaching royal power". The blame could be laid on too powerful royal officials or even on those who, while assaulting royal subjects on the highway, forcibly detained them till they paid ransom. ${ }^{3}$ In fact such offences could amount to felonies which were also serious crimes, but their treasonable nature was questionable.

Feudal lords who insisted on passing the Treason Statute might be interested in defining the limits of treason since the traitor's land was always forfeit to the crown while in case the perpetrator's offence was qualified as felony only, the land of the felon escheated to his immediate lord. ${ }^{4}$

The 1352 Statute defined as treason compassing or imagining the death of the king or of his spouse - the queen, or of their eldest son and heir. ${ }^{5}$ The interpretative formula required that "compassing" or "imagining" be manifested by some "overt act". ${ }^{6}$ Furthermore it was treason to violate the queen, or the king's eldest daughter unmarried, or the wife of the king's son and heir. ${ }^{7}$ According to the developed interpretation the violation involved both the rape as well as the carnal intercourse when permitted by the victim. Thus both sides could be blamed for committing treason on such occasion. This interpretation was applied vis-a-vis two wives of Henry VIII, Ann Boleyn and Catherine Howard. While yielding to the major perpetrator, the queens became accomplices in their own violation. ${ }^{8}$

Among other types of treason the Statute listed levying war against king or adhering to his enemies by giving them aid and comfort in the realm or elsewhere. As treason there were also qualified counterfeiting the king's privy seal or his money, and slaying some eminent king's officials, like chancellor, treasurer, king's justices etc.'

In the course of time the clauses of the Statute were subject to various interpretations. Thus at one time there might be blamed for high treason the one who uttered words that ridiculed the monarch or were hostile to him. There occurred sometimes even tragic, yet absurd accusations like that laid on the $14^{\text {th }}$ century inhabitant of London who said that he would make his son the heir of the crown (crown being the signboard over his household). The same may be said of the squire whose favourite deer was killed by the king during his hunting and who, while commenting on that, said that he would be happy if the killed animal got stuck together with its horns in the king's stomach. ${ }^{10}$ Only later the words unrelated to any conspiracy were not interpreted as treason and were qualified as misdemeanour.

\footnotetext{
2 TASWELL-LANGMEAD, English Constitutional History 573.

${ }^{3}$ BeLlamy, The Law of Treason in England in the Later Middle Ages 7.

${ }^{4}$ TAswell-Langmead, English Constitutional History 573; PluCKNetT, A Concise History of the Common Law 418-419.

${ }^{5}$ Select Documents of English Constitutional History 121-122.

${ }^{6}$ TASWELL-LANGMEAD, English Constitutional History 574.

${ }^{7}$ Select Documents of English Constitutional History 121-122.

${ }^{8}$ In case of Ann Boleyn there were doubts referring to evidence of her unfuithfulness, therefore she was accused also of conspiracy against the life of the monarch. On the accusations laid upon the wives of the monarch see: Cobbett's Complete Collection I, 410 seq.; Du CANN, English Treason Trials 42; SCARISBRICK, Henry VIII 348-350.

${ }^{9}$ Select Documents of English Constitutional History 121-122.

${ }^{10}$ For the examples of this type of interpretation of treason see BLACKSTONE, Commentaries on the Laws of England in Four Books 79.
} 
There also appeared controversies on how to interpret the levying-of-war clause. There was a problem what kind of unlawful assemblies might amount to the levying of war. Doubtless an assembly that tried to effect by force something what was of public or general concern might fall within the concept of levying war. But it was believed that this was not treason if the assembly was formed on the basis of some private quarrel or if it tended toward taking revange on some particular person. Such assemblies might be judged fellonies or trespasses. ${ }^{11}$

The lawyers engaged in drawing up the Treason Statute were aware that the list of specimens of treason contained therein was not exhaustive and that there might occur in future some offences whose nature might resemble treason and that there should be established some modus procedendi to cope with the problem. Therefore the Treason Statute was equipped with the proviso which allowed to submit to the king in parliament the cases raising doubts whether they were treason. ${ }^{12}$ Upon having decided that the case in question was treason, the parliament would refer it to the courts for further proceedings. In fact the parliaments engaged themselves not only in solving the dilemma referring to the nature of the crime but began to adjudicate the cases submitted to them. The decision on the guilt of the accused began to be taken while applying the law-creating modus procedendi. The question of guilt was subjected to voting. These developments led to the forming of Act of Attainder, a statute designed to attribute guilt to a specific individual blamed for the commission of the act supposed to be high treason. It is believed that Act of Attainder may have emerged as a result of the merger of several developmental lines in the history of English criminal proceedings. One of these lines provided for the possibility of condemning the perpetrators of serious offences on the basis of "king's record" or on "king's word". ${ }^{13}$ The point is that in the period of patrimonial state in which the ruler was an authentic iudex supremus, he could, while dispensing with the formalities of regular trial, condemn to death those whose crimes were notoriously known and who often (if they were rebels against the crown) fled the country. ${ }^{14}$ And indeed early Acts of Attainder condemning those whose acts were notoriously known and who therefore were not offerred the possibilities of defending themselves, may have been reminiscent of the on "the king's record" practice. As our further discussion will disclose, in the course of time Acts of Attainder were also applied to those whose offences were not notoriously known and who were fully attainable to the judiciary and could be tried by regular courts. In such cases however the applying of Act of Attainder allowed to ignore the scarcity of evidence and the political tone of the prosecution.

\section{High treason under the reign of the Tudors}

With the Tudor era there appeared the tendency to widen the concept of treason. At first this was due to the enlarged exploitation of the Act of Attainder which, as has already been mentioned,

\footnotetext{
11 Taswell-Langmead, English Constitutional History 576. For other examples illustrative of the interpretation of Treason Statute, see ibidem 574-586.

${ }^{12}$ Select Documents of English Constitutional History 121; STEPHEN, History of the Criminal Law of England 334.

${ }^{13}$ BeLLAMY, The Law of Treason in England in the Later Middle Ages 35-36; BARAN, Dzieje przestępstw politycznych w Anglii między średniowieczem a współczesnością 67.

${ }^{14}$ BeLlamy, The Law of Treason in England in the Later Middle Ages 125; LeHMBERG, Parliamentary Attainder 675677 .
} 
allowed the crown lawyers to dispense with being too scrupulous about the nuances of the concept of this crime and also released them from being too scrupulous about collecting evidence. Anyway, in case of Act of Attainder the accused was found guilty by virtue of the regular law-creating process in which his guilt was not so much proven but voted within the frame of typical procedure applicable to passing laws in the houses of parliament.

Under Henry VII there were already 138 cases of condemning various individuals through applying Act of Attainder. ${ }^{15}$ Yet the mode of proceeding against the accused was still within the tradition of Act of Attainder worked out in the Middle Ages. The acts of the accused were notoriously known. Among the accused there were often the pretenders (like Simnel or Warbeck) who challenged the right of the monarch to the throne, this being reminiscent of the War of the Roses. Condemning them and their allies in a simplified way was not deemed something glaringly unjust. On the contrary, it might comply with the earlier tradition of condemning obvious traitors on "the king's record" or on "the king's word"."

The things changed under the reign of Henry VIII. The condemning of the alleged traitors with the use of Act of Attainder began to depart from the generation-bred pattern. The involvement of those accused in the traitorous activities was not always notoriously known. Resignation therefore from trying them before regular courts before which their guilt would have to be fully proven could raise doubts. Besides, Henry VIII opened a new line of development of high treason concept. The docile parliaments of his time began to modify the idea of treason through new statutes adopted by the houses and allowing to qualify as high treason the acts of criticism of the monarch generated by his policy vis-a-vis the Church or his disordered matrimonial life. The 1352 Statute with its interpretation tradition would not suffice for punishing such criticism as treasonable act.

Yet before the modified treason statutes were passed the monarch's lawyers exploited the Act of Attainder to reach those who dared express criticism of the king. One of the first victim of this modus procedendi was a nun of Kent, Elizabeth Barton (1533). She criticized the monarch for his marriage with Ann Boleyn. She called upon the king to bring himself to reason and called upon the king's subjects to resist him. Qualifying the nun's words as seditious speech would not guarantee inflicting death penalty on her and thus would not produce a frightening effect ${ }^{17}$. Therefore the king's lawyers resorted to Act of Attainder by means of which death penalty in the aggravated form provided for the high treason acts was inflicted both on the nun and on several other individuals blamed for supporting her. The novelty introduced on that occasion consisted in this that - unlike the medieval rebels whose crimes were notoriously known and who often fled the country and therefore Act of Attainder might sometimes be the only tool with which they could be condemned without the regular trial, and their property confiscated - Barton and her accomplices were fully attainable to the administration of justice. ${ }^{18}$ Thus it was mere opportunism which inspired the crown prosecutors to exploit the Attainder instrument in this case.

Barton's case opened a long series of Attainder condemnations modelled on thus established pattern. What was striking was the nonchallant mode of formulating the blames laid on

\footnotetext{
15 LeHMberg, Parliamentary Attainder 676.

${ }^{16}$ BARAN, Dzieje przestępstw politycznych w Anglii między średniowieczem a współczesnością 77.

${ }^{17}$ Elton, Policy and Police 274; Lehmberg, Parliamentary Attainder in the reign of Henry VIII 681-682.

${ }^{18}$ BARAN, Dzieje przestępstw politycznych w Anglii między średniowieczem a współczesnością 78.
} 
the accused. In case of countess of Sarum (who was mother of cardinal Pole who stayed on the Continent and was known as supporter of the pope) and sixteen other individuals condemned with her and covered by one and the same Act of Attainder - hardly any evidence was demonstrated in the houses during the debate on her guilt. Four individuals of the aforementioned group were condemned for high treason in general tone without any specific deed of high treason nature being described as attributed to them. ${ }^{19}$ There were other condemnations in which obvious imperfections were detectable. Thus in case of Adam Fortescue who was a distant relative of Ann Boleyn, the accused was condemned for divers and sundry detestable and abominable treasons without explaining what they in fact were. ${ }^{20}$ Among other features characteristic of Attainders under Henry VIII's rule one may also point to the new mode by which the king used to give his assent to the condemning Act as adopted by the houses. He sometimes applied the formula soi droit fait comme il est desiré instead of the routine phrase used on such occasion which was: le roi le vault. ${ }^{21}$ By doing so the monarch probably tried to leave the impression that he only surrendered to the will of parliament in the condemning process although in fact it was him who set the entire affair on foot in the houses that were docile to him.

Another novelty appearing during Henry VIII's reign consisted in replacing the king's personal articulation of his assent to the bill of Attainder by a written patent issued by him under the great seal of England and only read in the houses. ${ }^{22}$ It was in this form that the king gave his assent to the Act of Attainder condemning to death his fifth wife Catherine Howard. ${ }^{23}$ The multiple condemnations already noted in Barton's case were another novelty. They reached their climax at the end of the 1530s and beginning of the 1540s, there being reported the case of 53 individuals condemned by one and the same Act of Attainder. ${ }^{24}$

During Henry VIII's reign Act of Attainder was applied against 130 individuals. 96 being condemned for high treason, 26 for misprision of treason, 5 for felonies and 3 for other offences. ${ }^{25}$ Thus Attainder proved to be a convenient instrument in the hands of a despotic ruler and was aimed to exclude regular trial which would not guarantee condemnation.

The post-henrician period was the beginning of the decline of Act of Attainder. In the next decades of the $16^{\text {th }}$ century there were only 6 cases of its application, which laid the foundations for gradual decreasing of this semi-judicial proceedings until its final disappearance in the $18^{\text {th }}$ century. ${ }^{26}$

As has been mentioned, apart from Acts of Attainder which fairly freely interpreted the 1352 Treason Statute, there appeared also in the 1530s the parliament-adopted laws broadening the concept of high treason by its new, previously unknown manifestations. One of the lines along which these statutes developed had a religion-tinted tone and was bound with Henry VIII's breach

\footnotetext{
${ }^{19}$ Cobbett's Complete Collection I 481-482; TASwELL-LANGMEAD, English Constitutional History 262.

${ }^{20}$ Lehmberg, Parliamentary Attainder 686.

21 LeHmberg, Parliamentary Attainder 682-686; BARAN, Dzieje przestępstw politycznych w Anglii między średniowieczem a współczesnością 78.

${ }^{22}$ Cobbett's Complete Collection III 450-451; LeHMBERG, Parliamentary Attainder 696.

${ }^{23}$ LEHMBERG, Parliamentary Attainder 696.

${ }^{24}$ LeHMBERG, Parliamentary Attainder 685.

${ }^{25}$ LEHMBERG, Parliamentary Attainder 701.

${ }^{26}$ LeHMBerg, Parliamentary Attainder. In the Stuart era the Act of Attainder reappeared (to mention only the cases of Strafford and Laud) in the turbulent years of Great Rebellion but its revival was not long-lasting.
} 
with Rome. And specifically it was treason to call the monarch a heretic or schismatic. ${ }^{27}$ Within the scope of the statutorily widened idea of treason there found themselves those who - contrary to the Act of Supremacy - refused to recognize the monarch as the head of the Church. Those who fell victim of the persecution arising from the newly-created legislation were above all the clergy, and among them such eminent personalities like Aughton, Webster, Laurence, Reynolds, Feron, Fisher or famous Thomas More. ${ }^{28}$

Another area in which new treason statutes appeared was the one connected with the monarch's disordered matrimonial life. The marriage with Catherine of Aragon was nullified within the English Church after the breach with Rome. This allowed the monarch to celebrate the bond of marriage with Ann Boleyn. From that time on the treason statutes referring to king's marriages tended to change kaleidoscopically. On the basis of new statutory law those who dared challenge the validity of the aforementioned marriage or legitimacy of princess Elisabeth born in it risked being tried and condemned for high treason. However later when Ann Boleyn herself was tried for high treason and beheaded, those who previously challenged her reputation could count on being pardoned. At the same time it was treasonable to maintain the validity of her marriage with the king. ${ }^{29}$ When Henry VIII's fifth wife, Catherine Howard, was beheaded on high treason charge it was made treason for any women to marry the king "unless she were chaste, or had previously revealed to bim ber former incontinence". ${ }^{30}$

Under the rule of next monarchs of the Tudor dynasty around the standard concept of treason based on the 1352 Statute there appeared and disappeared its modifications, particularly there were punished utterances that were ill-disposed toward the ruling monarch, although the utterances were not related to any conspiracy. Thus for instance under Mary Tudor uttering the opinion that Philip of Spain and his spouse Mary Tudor had no right to royal attribution and respect might amount to treason. ${ }^{31}$ Under Elisabeth, in reaction to the pope's bull excommunicating and deposing her, there were passed the statutes that made it treason to claim that she was a heretic, infidel, usurper of the crown etc. In the 1580s Catholic priests who - contrary to the requirement of law - did not quit the realm were threatened with the penalty for high treason. ${ }^{32}$

\section{Conclusion}

In the English Middle Ages, in 1352, there was adopted a Statute that for centuries established a fundamental concept of the law of treason. Among the specimens of this crime the Statute listed compassing or imagining the death of the king and some of his closest relatives (overt act confirming the imagining being required), levying war against the king or adhering to his enemies, slaying eminent functionaries of the crown, counterfeiting great seal or money etc. The respective clauses of the Statute were subjects to various interpretations which were worked out throughout

\footnotetext{
${ }^{27}$ TASWELL-LANGMEAD, English Constitutional History 260.

${ }^{28}$ Cobbett's Complete Collection I, 472-477; on Thomas More see the Dictionary of National Biography XIII, 884; also LeHMBERG, Parliamentary Attainder 204 seq.

29 TASWELL-LANGMEAD, English Constitutional History 260.

30 TASWELL-LANGMEAD, English Constitutional History 260.

${ }^{31}$ HARDING, A Social History of English Law 80.

32 TASWELL-LANGMEAD, English Constitutional History 334-337.
} 
the centuries. The legislators considered the Statute to be non-exhaustive. Therefore they equipped it with a proviso according to which the cases raising doubts on whether they amounted to treason or not might be submitted to king in parliament for the decision. In practice, on such occasions, the parliaments began to decide not only on the qualification of the crime submitted to their debate but, if they deemed it treason, they took to adjudging the submitted case and producing the final sentence. On such occasion they resorted to semi-judicial modus procedendi. This tendency, while merging with some other developmental lines in the English penal procedure (including the medieval tradition of condemning notorious offenders "on the king's record" or "on the king's word") led to the emergence of Act of Attainder. The latter particularly dynamically developed under the reign of the Tudor dynasty. In that era the condemning of the factual or alleged opponents of the monarch with the use of Act of Attainder betrayed a lot of opportunism. The decision that the act with which the alleged perpetrator was charged was treason used to be taken through regular lawcreating process involving both houses of parliament, the guilt of the accused being declared through voting and not necessarily resulted from the evidence-based proceedings. Scarcity of evidence was detectable in a lot of Attainder cases and the exploitation of this procedural device was reflective of the tyrannical rule of Henry VIII under whose reign Attainder was exploited against 130 individuals, 96 of them being accused of high treason.

Apart from the broad interpretation of treason with the use of Act of Attainder, the criticism of the monarch's controversial policy vis-à-vis the Church and of his disordered matrimonial life inspired Henry VIII to force the docile parliaments of his days to adopt laws that qualified as treason utterances that were ill-disposed toward the monarch although they were not related to any conspiracy. To some extent this line of legislation survived under the next rulers of the Tudor dynasty although the Act of Attainder itself began to decline.

\section{Bibliography and sources}

AdAms, George Burton - STEPHENs, H. Morse (eds.): Select Documents of English Constitutional History. New York 1954

BARAN, Kazimierz: Dzieje przestępstw politycznych w Anglii między średniowieczem a współczesnością. Cracow 2000

Bellamy, J. G.: The Law of Treason in England in the Later Middle Ages. Cambridge 1970

BLACKSTONE, William: Commentaries on the Laws of England in Four Books. London 1836

Cobbett's Complete Collection of State Trials for High Treason and Other Crimes and Misdemeanours I-XXXIII. London 1809-1826

Du CANN, C. G. L.: English Treason Trials. London 1964

ELton, Geoffrey Rudolph: Policy and Police. The Enforcement of the Reformation in the Age of Thomas Cromwell. Cambridge 1972

HARDING, Alan: A Social History of English Law. Penguin Books 1966

LEHMBERG, Stenford E.: Parliamentary Attainder in the reign of Henry VIII. Historical Journal, vol. 18/1975 675702.

PLUCKNETT, Theodore F. T.: A Concise History of the Common Law. London 1948

SCARISBRICK, John Joseph: Henry VIII. London 1969

STEPHEN, James Fitzjames: History of the Criminal Law of England I. London 1883

STEPHEN, Leslie - LEE, Sidney (eds.): Dictionary of National Biography. London, publ. since 1917

Taswell-Langmead, Th. Pitt: English Constitutional History from the Teutonic Conquest to the Present time. Rev. and enlarg. by Theodore F. T. PLUCKNETT. London 1946 